\title{
Problem of Clogging in Drainage Systems in the Examples of the Żur and Podgaje Dams
}

\author{
Witold Sterpejkowicz-Wersocki \\ Gdańsk University of Technology, Faculty of Civil and Environmental Engineering, \\ ul. G. Narutowicza 11/12, 80-233 Gdańsk, Poland, e-mail: wste@pg.gda.pl
}

(Received October 02, 2014; revised December 16, 2014)

\begin{abstract}
Drainage plays an extremely important role in hydraulic structures, such as earth dams. Observations of drainage in hydraulic structures under various soil conditions indicate that the phenomenon of clogging can lead to a radical reduction in the efficiency of drainage, making it non-functional within a few years after construction. This article describes the problems of drainage clogging by iron oxide in the examples of the Żur and Podgaje dams.
\end{abstract}

Key words: drainage, clogging, hydraulic engineering

\section{List of principal symbols}

A - cross-sectional area, $L^{2}$,

$d \quad-$ diameter of the drain, $L$,

I - slope of the hydraulic grade line or the slope of the drainage pipe dimensionless,

$n \quad-\quad$ Manning coefficient, $L^{-1 / 3} T$,

$Q \quad$ - discharge rate, $L^{3} T^{-1}$,

$R_{h} \quad-$ hydraulic radius, $L$.

\section{Introduction}

Drainage systems in hydraulic facilities are an extremely important element of these structures. A typical lifespan of a drainage system, depending on the solution, can be estimated at a dozen to several dozen years. During this period, drain efficiency is gradually reduced, which is normal, but in some cases may lead to a sharp deterioration in the efficiency of the drainage system. Reduction in the drain efficiency is related to clogging, which reduces the number or size of pores involved in the groundwater flow.

Depending on the factors that limit the free flow of groundwater, several types of clogging can be distinguished: 
- Mechanical - the classic kind of clogging, associated with the retention and deposition of ultrafine particles of soil, which have been moved due to the suffosion process,

- Chemical - associated with the precipitation from groundwater of some chemical compounds that hinder the free flow of water into the drain,

- Biological - associated with the growth of fungi or mold, or with the hypertrophy of the root mass in the drainage area,

- Mixed - when the above-mentioned types of clogging occur together.

The clogging of screen slots by an accumulation of iron hydroxide precipitates is caused by the simultaneous abstraction of oxygen-containing and iron-containing groundwater. This condition is fulfilled by the presence of an oxygen-iron (II) redox interface in the drained aquifer. The problem of the clogging of filter slots is widely known and applies not only to drainage systems, but also to wells abstracting groundwater from aquifers (van Beek 2012).

Soluble $\mathrm{Fe}^{2+}$ flowing in groundwater enters a different environment as it approaches the drain and passes through the drain envelope. If some oxygen is present in this area, certain filamentous and rod-shaped bacteria will precipitate some of the $\mathrm{Fe}^{2+}$ as insoluble $\mathrm{Fe}^{3+}$ and incorporate it into ochre. Iron-precipitating bacteria must be present for extensive clogging to occur, even when other conditions are just right for the chemical precipitation of iron (Stuyt, Dierickx, Beltran 2005).

The observations of drainage in hydraulic structures under various soil conditions indicate that the phenomenon of clogging can lead to a radical reduction in the efficiency of drainage, making it non-functional within only a few years after construction. A particularly serious problem is the clogging with iron oxide precipitated from the groundwater around the drainage system. Examples of this type of clogging, quite common in place Pomerania, are discussed below for two earth dams built in the late 1920s and early 1930s in Żur on the Wda river and in Podgaje on the Gwda river.

\section{Drainage of the Earth Dam in $\dot{Z} u r$}

The earth dam in Żur was built in 1928-1930 (Fig. 1). It dams up the Wda (Black Water) river to the elevation of $67.5 \mathrm{~m}$ above sea level. The length of the dam at the crown is $175 \mathrm{~m}$, crown elevation $70.0 \mathrm{~m}$ a.s.l., base elevation about $52.0 \mathrm{~m}$ a.s.l. It is an earth dam sealed with an internal clay core.

The main technical problem that occurs during the lifetime of the earth dam are filtration phenomena, in particular the rising of the phreatic line, caused by the clogging of the drainage system.

To intercept the seepage a drainage prism (rock toe filter) was designed and constructed in 1928-1929 at the base of the downstream slope. In its original form, the drainage worked for over 40 years.

In the mid 1970s, a decision was made to build a new drainage system, as the rock toe filter had been clogged, and it was pointless to renovate the filtration capacity 


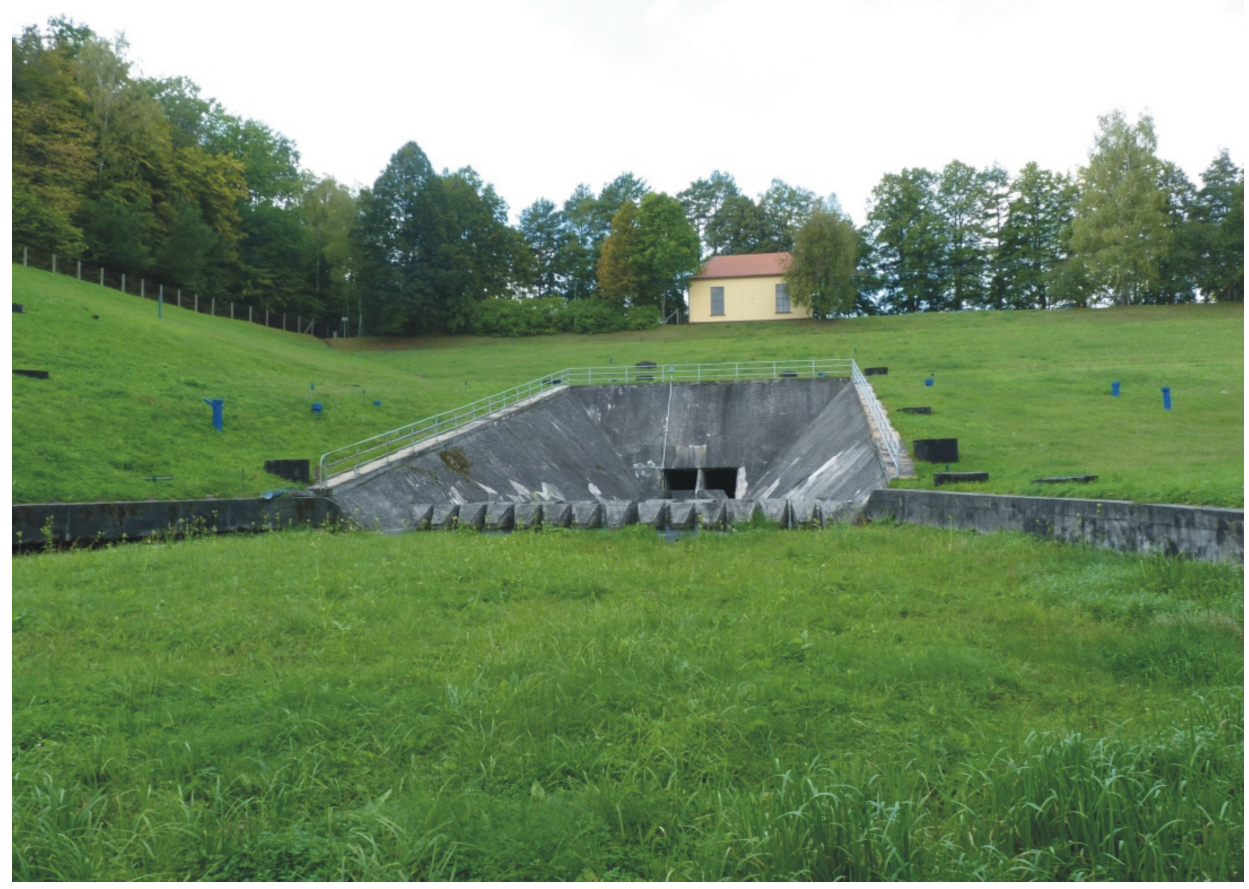

Fig. 1. General view of the Żur earth dam and the bottom outlet

of the rip-rap that had worked since the beginning of the construction. There is no further information about the type of clogging. It was probably related to the development of vegetation, with layers of soil and root, and the consequent reduction in the permeability of the drainage prism at the base of the downstream slope of the dam.

A new drainage system with a total length of approx. $170 \mathrm{~m}$ and a diameter of $300 \mathrm{~mm}$ was constructed in place of the rock toe filter, that had an area equal to about $1400 \mathrm{~m}^{2}$. The drainage system was likely to eliminate the impact of surface factors, which had led to the clogging of the original rock toe filter.

As early as the 1990s, much sooner than for the rock toe filter, the rising water level in the piezometers, indicated that clogging had emerged,again. This suggests that the causes of clogging for rock-fill and tubular drains could be different because of a fundamental difference in the method of dewatering. The original rip-rap drain was a type of "area drainage" with a much larger drain surface, and therefore it was more resistant to clogging processes.

Further works related to the reduction of seepage in the earth dam were local and temporary - concerned only with the outlet area. In the existing deep wells, for the dewatering of the earth dam during the construction of the tubular drain, two siphons were installed. This led to the reduction of seepage pressure only locally. As previously, after 2-3 years there was a rise in the water level in the body of the dam. 


\section{Assessment of the Clogging Process}

The assessment of clogging was based on:

- the results of the chemical analyses of samples taken from the reservoir, drain, and several piezometers, the measurement of drain performance,

- the results of grain size analyses of sandy soil samples collected during drilling.

- The results of the chemical analyses are summarized in Table 1 below (Kot et al 2007). The placemarks of water samples:

$\mathrm{Z}$ - a sample from the surface layer of water in the reservoir,

$\mathrm{D}$ - a sample from the outlet of the drain,

P-21, P-22, P-26 - samples from piezometers (taken after a pumping time necessery for obtaining pure water without suspension),

P-39 - a sample from piezometer located in the downstream area, near the river.

Table 1. Results of the chemical analyses of water

\begin{tabular}{|c|c|c|c|c|c|c|c|c|c|c|}
\hline & $\mathrm{pH}$ & $\begin{array}{c}\text { Total } \\
\text { alkalinity } \\
\text { mval/dm }\end{array}$ & $\begin{array}{c}\text { Total } \\
\text { hardness } \\
\mathrm{mval} / \mathrm{dm}^{3}\end{array}$ & $\begin{array}{c}\text { Chlo- } \\
\text { rides } \\
\mathrm{mg} / \mathrm{dm}^{3}\end{array}$ & $\begin{array}{c}\text { Dissolved } \\
\text { oxygen } \\
\mathrm{mg} / \mathrm{dm}^{3}\end{array}$ & $\begin{array}{c}\text { Manga- } \\
\text { nese } \\
\mathrm{mg}^{2} \mathrm{dm}^{3}\end{array}$ & $\begin{array}{c}\text { Total } \\
\text { iron } \\
\mathrm{mg} / \mathrm{dm}^{3}\end{array}$ & $\begin{array}{c}\mathrm{Fe}^{3+} \\
\mathrm{mg} / \mathrm{dm}^{3}\end{array}$ & $\begin{array}{c}\mathrm{Fe}^{2+} \\
\mathrm{mg} / \mathrm{dm}^{3}\end{array}$ & $\begin{array}{c}\text { Sulpha- } \\
\text { tes } \\
\mathrm{mg} / \mathrm{dm}^{3}\end{array}$ \\
\hline Z & 7.37 & 3.1 & 3.32 & 9.22 & 11.7 & 0.0 & 0.2 & 0.2 & 0.0 & 26.0 \\
\hline $\mathrm{D}$ & 7.11 & 4.0 & 4.0 & 7.44 & 5.1 & 0.65 & 1.1 & 1.0 & 0.1 & 15.0 \\
\hline $\bar{P} 21$ & 7.17 & 2.2 & 1.6 & 5.32 & 0.2 & 0.2 & 1.0 & 0.7 & 0.3 & 3.25 \\
\hline $\mathrm{P} 22$ & 6.97 & 4.0 & 3.64 & 7.1 & 0.0 & 0.1 & 7.6 & 6.8 & 0.8 & 7.25 \\
\hline P26 & 6.98 & 3.8 & 3.76 & 7.44 & 0.0 & 0.4 & 4.8 & 3.6 & 1.2 & 13.0 \\
\hline P39 & 6.94 & 3.8 & 4.08 & 5.32 & 0,32 & 0.15 & 1.0 & 0.9 & 0.1 & 17.25 \\
\hline
\end{tabular}

These results lead to the following observations:

It is known that

- a high oxygen content is characteristic of surface waters,

- a low iron content is characteristic of surface waters,

- clogging is caused by iron compounds oxidized to $\mathrm{Fe}^{3+}$,

- a necessary condition for the oxidation and precipitation of iron is the presence of oxygen.

In the samples collected:

- high levels of iron were found in water samples taken from piezometers P-22 and $\mathrm{P}-26$, contained in the body of the dam (the ordinate of the foundation of the filters approx. $43 \mathrm{~m}$ a.s.l., or about $8 \mathrm{~m}$ below the drainage foundation),

- there was no oxygen in the groundwater taken from piezometers P-22 and P-26,

- a high oxygen content was found in the water from the drain; this water also had a small iron content compared with the samples from the piezometer.

The above results of chemical analyses raise the following questions:

- which factor causes the high oxygen content in the sample taken from the drain? 
- what is the reason for a significantly lower iron content in the sample taken from the drain compared to the iron content in samples collected from the piezometers - even though the drainage receives the same groundwater?

The answers to these questions can be found in:

- the results of measurements of drain performance,

- the technical parameters of the drainage system,

- changes in groundwater flow conditions in the contact zone with the drainage system.

The amount of water in the drainage system is determined by the hydraulic conductivity of the layer in which the drain is situated.

- The highest hydraulic conductivity of sands near the drain is $0.000076 \mathrm{~m} / \mathrm{s}$ (piezometer P-25).

- Water flow through $1 \mathrm{~m}$ of drainage pipe with a diameter of $0.3 \mathrm{~m}$ is $82 \mathrm{l} / \mathrm{h}=1.36$ liters/min. The total length of the drainage is $170 \mathrm{~m}$.

Thus, the drain efficiency $=232$ liters $/ \mathrm{min}$.

This amount of water is drained through a drain with a diameter of $0.3 \mathrm{~m}$. The throughput of such a drain, at a slope of $5 \%$, can be estimated on the basis of the Manning equation (Eq. 1):

$$
Q=\frac{1}{n} \cdot R_{h}^{\frac{2}{3}} \cdot I^{\frac{1}{2}} \cdot A
$$

where:

$$
\begin{aligned}
& n=0.025 \mathrm{~m}^{-1 / 3} \mathrm{~s} \quad-\text { Manning coefficient; } \\
& I=5 \%=0.05 \quad-\quad \text { slope of the hydraulic grade line; } \\
& d=0.3 \mathrm{~m} \quad-\text { diameter of the drain; } \\
& R_{h}=d / 4=0.075 \mathrm{~m} \quad-\text { hydraulic radius; } \\
& A=0.07065 \mathrm{~m}^{2} \quad \text { - cross-sectional area. }
\end{aligned}
$$

Thus: $Q_{\text {drain }}=0.1127 \mathrm{~m}^{3} / \mathrm{s}=113 \mathrm{l} / \mathrm{s}=6780 \mathrm{l} / \mathrm{min}$.

This means that the hydraulic capacity of the drain tube is much greater than the water flow, so the drainage pipe is only partially filled with water, which is also confirmed by the observation of drainage pipes at the dam.

The above rough calculation indicates that in the drain, and thus in the aquifer around it, there is air, which explains a large oxygen content in the sample taken from the drain.

The presence of air in the drain also explains the significant difference in iron concentration between the groundwater and drain water samples: iron precipitates in the contact zone between the groundwater and the air in the drain, i.e. at the outer surface of the drain, clogging the pipe's perforations and the whole drain. This reduces the amount of water absorbed by the drainage system. 
There follows another question: what is the time of clogging the perforation, pores, and sand-gravel layers of the drainage system for particular concentrations of iron in the groundwater?

The assessment of the duration of clogging was performed assuming that:

- clogging is caused by the precipitation of trivalent iron $\mathrm{Fe}^{+3}$ compounds from water,

- the content of $\mathrm{Fe}^{3+}$ is $6.8 \mathrm{mgFe} / \mathrm{dm}^{3}$ (piezometer P-22),

- the precipitation of the entire content of iron $\mathrm{Fe}^{3+}$ takes place in the sand pores and crevices of the drain in the contact zone between the groundwater and air,

- effective porosity $n_{e}=0.2$,

- the causes of clogging in the rock-fill prism and drain regions are the same.

This implies that:

- the amount of iron $\mathrm{Fe}^{3+}$ is $6.8 \mathrm{mg} / \mathrm{liter}=0.0000068 \mathrm{tons} / \mathrm{m}^{3}$ of water,

- the flow of water to 1 meter of the layer is $0.082 \mathrm{~m}^{3} / \mathrm{h}=718 \mathrm{~m}^{3} /$ year,

- the amount of trivalent iron in water flowing during one year is $0.005 T=5 \mathrm{~kg}$,

- the surface of the pores in the rock-fill prism is $1400 \mathrm{~m}^{2} \times 0.2=280 \mathrm{~m}^{2}$,

- the surface of the pores in the filter layer of the tubular drain with a diameter of $0.3 \mathrm{~m}$ and a length of $170 \mathrm{~m}$ is $64 \mathrm{~m}^{2}$.

Therefore, $5 \mathrm{~kg}$ of iron could be deposited annually in the pores of the surface of $280 \mathrm{~m}^{2}$ (in the rock toe filter) and $64 \mathrm{~m}^{2}$ (around the drain). To estimate the consequences of the precipitation of $5 \mathrm{~kg}$ of iron, the following reasoning was carried out.

To clog the pores, a thin film of iron oxide is sufficient, assumed here as $1 \mathrm{~mm}$. The volume of such a film on the surface of $1 \mathrm{~m}^{2}$ is $10000 \mathrm{~cm}^{2} \times 0.1 \mathrm{~cm}=1000$ $\mathrm{cm}^{3}=1 \mathrm{dm}^{3}$.

Compounds of iron $\mathrm{Fe}^{3+}$ are carried by water, which means that their weight (taking the buoyancy into account) is approx. $1 \mathrm{~g} / \mathrm{dm}^{3}$. One liter contains $1 \mathrm{~g}$ of dissolved iron compounds. Thus $1 \mathrm{~kg}$ of iron $\mathrm{Fe}^{3+}$ takes a volume of $1 \mathrm{dm}^{3}$, which means that $1 \mathrm{~kg}$ of iron is enough to $\operatorname{clog} 1 \mathrm{~m}^{2}$ of pores.

On the basis of the above analysis, it can be estimated that the total filling of pores with deposits of iron takes 56 years in the drainage prism, but only 13 years around the tubular drain.

These results provide a merely approximate estimate of the time in which the clogging of the drain and prism occurs, yet they fully explain the cause of the dysfunction of drainage systems in earth dams.

A factor favoring the precipitation of iron from the groundwater is the presence of oxygen. In the case of drainage pipes, only partly filled with water, the air (oxygen) "enters" the whole installation, which promotes the oxidation of iron on its surface. In the case of a rock toe filter, the process takes place in the subsurface zone of water 
flow, wherein clogging was probably stimulated by the development of a root zone and vegetation.

\section{Drainage of the Podgaje Earth Dam}

The hydropower plant Podgaje is located in the northern part of the Wielkopolska region, approximately $10 \mathrm{~km}$ from the city of Jastrowie. It was launched in 1929 as the first hydropower plant in the cascade of the Gwda river. As a result of damming the river Gwda by the earth dam (Fig. 2) with a length of $520 \mathrm{~m}$, a reservoir was created, which covers an area of 116 hectares and has a capacity of 3.87 million $\mathrm{m}^{3}$, from which water is supplied to the power plant by a diversion channel with a length of about $900 \mathrm{~m}$.

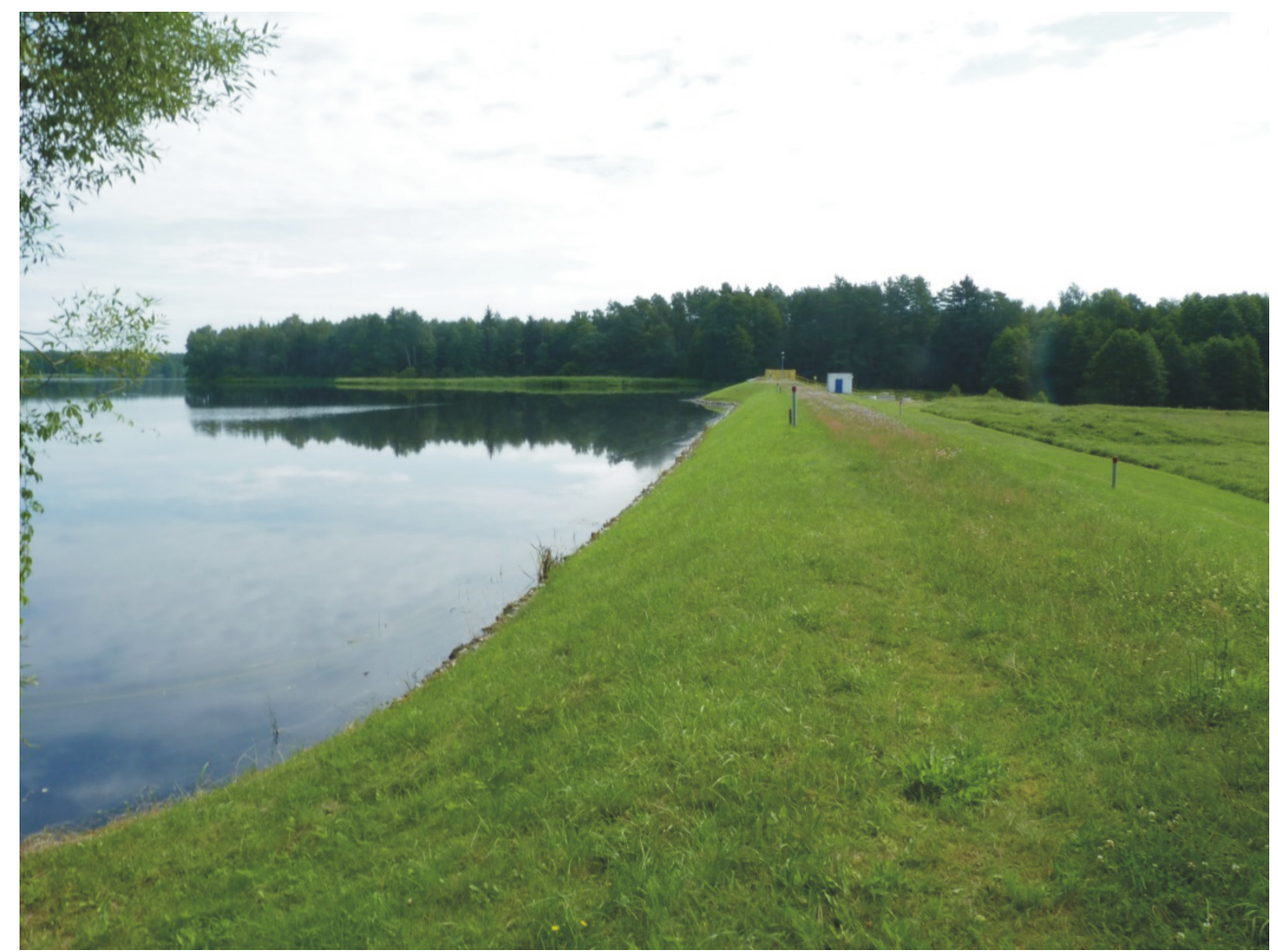

Fig. 2. General view of the Podgaje earth dam

This earth dam is also afflicted with cyclical drainage dysfunctions caused by clogging with iron compounds. Its present drainage system was constructed in 1991. It consists of ceramic drainage pipes, a sand filter, and a geotextile.

During operation, a slow but steady increase in pressure filtration can be observed. Inside wells and drainage pipes, clogging is caused by iron oxide in the form of fer- 


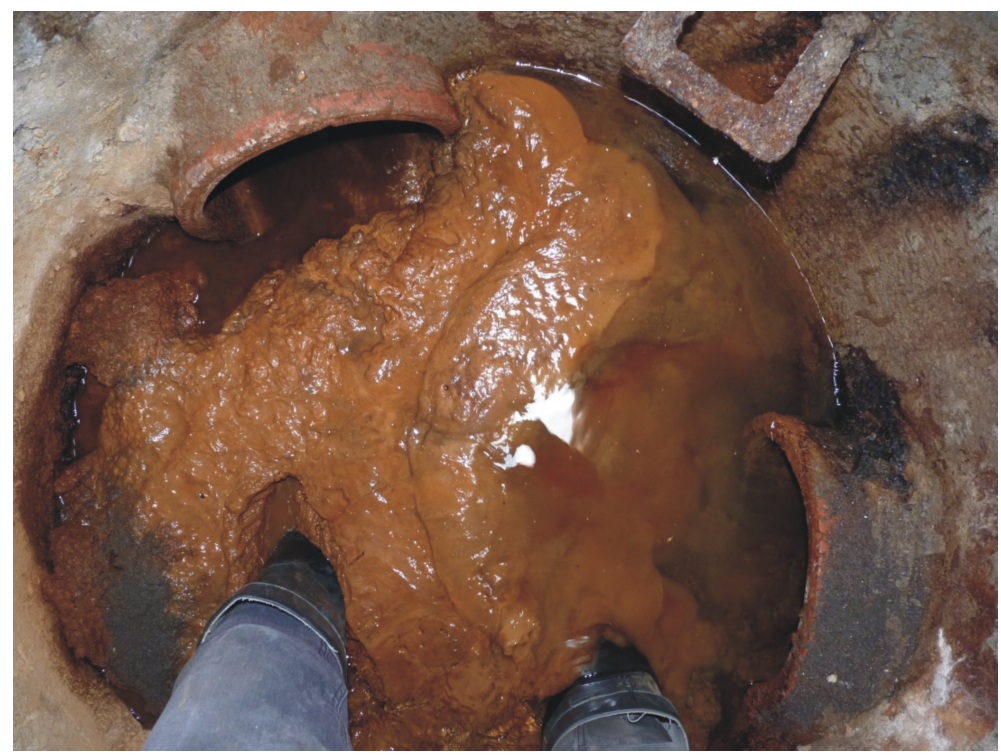

Fig. 3. Ferruginous substance in a well

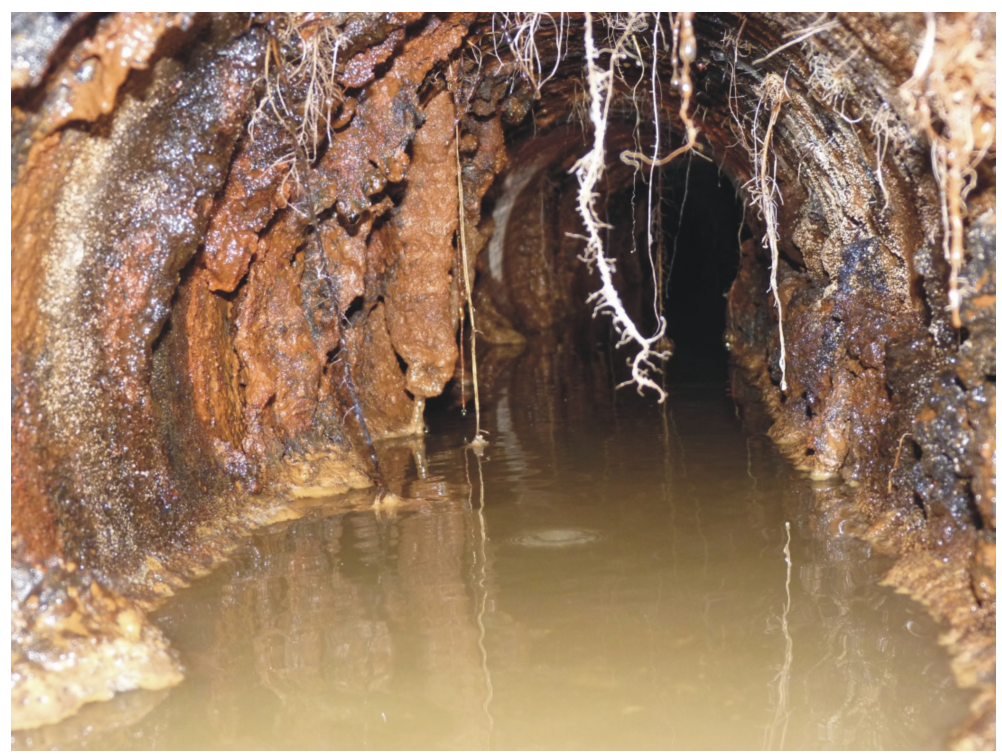

Fig. 4. Ferruginous substance in a pipe

ruginous deposits, which reappear within a few months after being removed (Fig. 3 and Fig. 4).

Some of the drainage wells have been mounted only on a geotextile (without a concrete plug). Inside the wells, a severe clogging of the geotextile can be observed, which 
results in a bulge of the material (Fig. 5) caused by groundwater pressure, which is stabilized at a height of about $2 \mathrm{~m}$ above the bottom of the well.

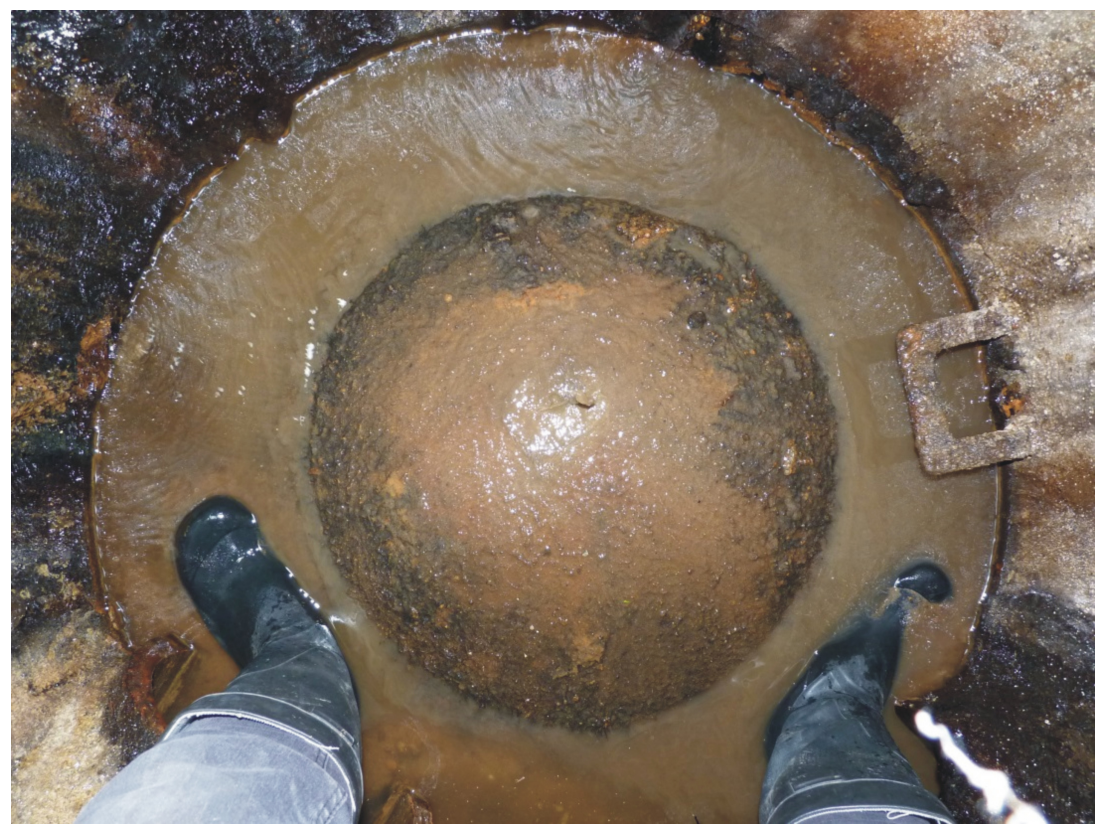

Fig. 5. A bulge caused by groundwater pressure in geotextile at the bottom of a well

The technical condition of the drain and the observed upward trend of the phreatic curve clearly demonstrate the need to restore the drainage system. Under the existing conditions, it is impossible to protect the drain effectively against the precipitation of iron oxide, but measures should be taken to delay the consequences of progressive clogging.

These measures include the replacement of the geotextile as a drainage layer with classic mineral inverted filters. The author's experiences (Bolt, Sterpejkowicz-Wersocki 2006; Sterpejkowicz-Wersocki Szudek 2011, 2013; Sterpejkowicz-Wersocki 2013) regarding the effectiveness of geotextiles in filtration and drainage solutions indicate that the presence of ferruginous groundwater results in the formation of an impermeable film on the surface of geosynthetics. In other cases, geotextiles retain their function, acting effectively as filters.

\section{Conclusion}

Clogging is a process of the precipitation of iron oxidized to a trivalent form. This precipitation reduces soil porosity and thereby decreases the hydraulic conductivity of the soil around the drainage system. The precipitation occurs in the contact zone between the air and groundwater. 
The contact zone is a zone of "transition" from the natural groundwater aquifer to the drainage layer as a layer of different filtration conditions. Oxidation occurs in the presence of oxygen from the air, and thus in the contact area between the drain and groundwater. In the case of drainage pipes, partly filled with water, the air "enters" the whole installation, which promotes the oxidation of iron on its surface.

There is no known economical, long-term method for effectively controlling ochre clogging in drains. A graded gravel envelope is the best way to extend the lifetime of a drainage system. It may, however, still clog under conditions of severe ochre potential. Relatively thin synthetic envelopes, such as geotextiles, present the greatest risk (Stuyt, Dierickx, Beltran 2005). Surveys of selected drainage sites show that ochre clogging of drains wrapped with synthetic materials occurs first in the slots and valleys of pipe corrugations, and can be present in amounts sufficient to cause drain failure. These materials are relatively easily clogged by ochre deposits because iron precipitating bacteria (Thiobacillus ferrooxidans) grow across the voids in the fabrics. Of all thin synthetic envelopes, knitted polyester envelopes are the least vulnerable to ochre clogging.

Examples of drainage systems indicate serious problems with the maintenance of efficient drainage in the presence of iron in the groundwater. Under such conditions, the use of geotextiles should be avoided and the solutions adopted should eliminate the causes of clogging. One of such solutions is to place filters in an area where air access is excluded, and the filters are completely submerged, eg. as a system of vertical wells, operating on the self outflow or siphon. Thus the risk of chemical clogging by iron oxide is minimized, and the failsafe operation of the drain is extended.

\section{References}

Bolt A., Sterpejkowicz-Wersocki W. (2006) Durability of geosynthetics and filtration issues, Proc. of Conference "Geosyntetyki i Tworzywa Sztuczne w Geotechnice i Budownictwie Inżynieryjnym”, Częstochowa, 11-11 May (in Polish), 35-42.

(Kees) van Beek C. G. E. M. (2012) Cause and prevention of clogging of wells abstracting groundwater from unconsolidated aquifers, IWA Publishing.

Kot A., Granatowicz J., Podleśny A., Sukowski T. (2007) Model of water circulation in the vicinity of the hydroelectric power station Żur, Pracownia Modelowania Hydrogeologicznego, Chwaszczyno (in Polish).

Stuyt L. C. P. M., Dierickx W., Martinez Beltran J. (2005) Materials for subsurface land drainage systems, Food and Agriculture Organization of the United Nations, Irrigation and drainage paper, 60 rev. 1.

Sterpejkowicz-Wersocki W. (2013) The durability of geosynthetics in filtration applications in hydraulic engineering, Inżynieria Morska i Geotechnika (in Polish), 34 (5), 447-456.

Sterpejkowicz-Wersocki W., Szudek W. (2013) Renovation of drainage system in hydropower plant Podgaje, Monografie Instytutu Meteorologii i Gospodarki Wodnej, IMGW PIB, Warszawa (in Polish).

Sterpejkowicz-Wersocki W., Szudek W. (2011) Renovation of drainage system in hydropower plant Żur, Monografie Instytutu Meteorologii i Gospodarki Wodnej, IMGW PIB, Warszawa (in Polish). 